\title{
STUDY OF MORPHOLOGICAL CHARACTERISTICS OF POLLEN GRAINS OF ARONIA MITSCHURINII A.K. SKVORTSOV \& MAITUL.
}

\section{Grygorieva Olga ${ }^{1 *}$, Klymenko Svitlana ${ }^{1}, V^{2}$ inogradova Yulia ${ }^{2}$, Motyleva Svetlana ${ }^{3}$, Gurnenko Ivan ${ }^{1}$, Narcyz Piórecki $^{4,5}$, Brindza Jan $^{6}$}

\author{
${ }^{1}$ M.M. Gryshko National Botanical Garden of Ukraine of National Academy of Sciences, Kyiv, Ukraine \\ ${ }^{2}$ N.V. Tsitsin Main Botanical Garden of Russian Academy of Sciences, Moscow, Russia \\ ${ }^{3}$ All-Russian Institute of plant breeding and gardening and nursery, Moskow, Russia \\ ${ }^{4}$ Arboretum and Institute of Physiography in Bolestraszyce, Przemysl, Poland \\ ${ }^{5}$ University of Rzeszow, Rzeszow, Poland \\ ${ }^{6}$ Faculty of Agrobiology and Food Resourses, Slovak University of Agriculture in Nitra, Nitra, \\ Slovak Republic
}

\section{Received: 07. 11.2018 Revised: 10.11.2018 Published: 10.12. 2018}

Morphology of pollen grain was described for nine Aronia mitschurinii A.K. Skvortsov \& Maitul. phenotypes (AM-01 - AM-09) at the laboratory of Department of Tropical and Subtropical plants of M.M. Gryshko National Botanical Garden of NAS of Ukraine (Kyiv) and Institute of Biodiversity Conservation and Biosafety at Slovak University of Agriculture in Nitra using an electron microscope Carl Zeiss LS 15. The measurement of morphometric parameters was carried out on 50 pollen grains from each phenotype using the AxioVision Rel. 4.8.2.0 program. The measurements were made in micrometer $(\mu \mathrm{m})$. The length of polar axis $(P)$ and the equatorial diameter $(E)$ of grain, $P / E$ ratio were measured and their variation was compared among studied genotypes. SEM investigations showed that the pollen grains are radial-symmetrical, isopolar, oblong-ellipsoid and 3- and 4-colporate. Texture is sinuous-tuberculate in equatorial zone and finely bumpy in polar zone. The polar axis and equatorial diameter of pollen grains values were varied from 34.16 to $50.14 \mu \mathrm{m}$ and from $16.10 \mu \mathrm{m}$ to $25.71 \mu \mathrm{m}$, respectively. This study showed that there were differences among the phenotypes in all measured factors. It is known that phenotypic variability is an evolutionarily fixed response of any group of organisms with a constant genotype to changes in environmental conditions and it is adaptive. Therefore, our research suggests that all individuals forming the introduction population of Aronia mitschurinii are sufficiently adapted to the conditions of M.M. Gryshko National Botanical Garden of NAS of Ukraine.

Keywords: Aronia mitschurinii, phenotype, pollen, SEM, morphology

*Corresponding author: Grygorieva Olga, M.M. Gryshko National Botanical Garden of Ukraine of National Academy of Sciences, Kyiv, Timiryazevska 1, 01014 Kyiv, Ukraine olgrygorieva@gmail.com 


\section{Introduction}

Research into the morphological characteristics of pollen grains by scanning electron microscopy (SEM) from specific genotypes and cultivars are important and useful for taxonomy, phylogeny, palaeobotany, breeding programmes, e.g., Pyrus spp. (Westwood and Challice, 1978; Motyleva et al., 2017), Vitis vinifera L. (Ahmedullah, 1983), Prunus cerasus L. (Miaja et al., 2000), Olea europaea L. (Javady and Arzani, 2001), Prunus armeniaca L. (Arzani et al., 2005), Cornus mas L. (Mert, C. 2009), Diospyros spp. (Grygorieva et al., 2010, 2013, 2017), Corylus avellana L. (Nikolaieva et al., 2014), Ziziphus jujuba Mill. (Rouhakhsh et al., 2014), Castanea sativa Mill. (Grygorieva et al., 2015), Cydonia oblonga Mill. (Radović et al., 2016), and Cichorium intybus L. (Adamchuk et al., 2017). Size, shape, surface morphology, and ultrastructure of pollen grains are of great importance in the characterization of the pollen grains (Erdtman, 1966; Fogle, 1977; Martens and Fretz, 1980; Brindza and Brovarskyi, 2013; Dyakova, 2014; Brovarskyi et al., 2017; Chlebo and Adamchuk, 2017).

The characteristics of pollen grains are often additional diagnostic features for taxa of various ranks, as shown for Caragana arborescence Lam. (Kuklina et al., 2015), Lupinus polyphyllus Lindl. (Vinogradova et al., 2012), Robinia spp. (Vinogradova et al., 2013), Solidago L. complex (Vinogradova, 2012).

The properties of the pollen grains of different phenotypes of Aronia mitschurinii have not been evaluated in detail yet.

The knowledge of pollen morphological characteristics can be an adequate method for identification phenotypes of Aronia mitschurinii.

\section{Material and methodology}

\section{Locating trees and data collection}

The pollen of 9 Aronia mitschurinii phenotypes (AM-01 - AM-09) from the collection of M.M. Gryshko National Botanical Garden of NAS of Ukraine (NBG) was investigated.

\section{Pollen grains collection}

Freshly flowers (not opened) were collected randomly from the different genotypes at the balloon stage (May 2018). Pollen samples released from dry flowers were further dried under laboratory conditions. The dry pollen was used for a microscopic study of morphological characteristics. The samples of pollen grains were applied to double-tape, fastened to metal object tables with $10 \mathrm{~mm}$ diameter.

\section{Scanning electron microscopy (SEM)}

The pollen grains were studied at the laboratory of Department of Tropical and Subtropical plants of NBG and Institute of Biodiversity Conservation and Biosafety of Slovak University of Agriculture in Nitra (IBS) using an electron microscope Carl Zeiss LS 15, and the microphotographs were taken. The comparative morphological studying of the pollen grains was performed according to the working rules on the SEM JEOL JSM-6390 in the conditions of 
low vacuum $(P=60 \mathrm{~Pa})$ with the following zooming: 500 times - during the measurements; 1000-10000 times - while taking the pictures of the exine sculpture features. Using the regime of low vacuum allows to perform the pollen studying without its preliminary chemical treatment and to receive undistorted data about the research object that makes the process of the probe preparation easier. Typical exine patterns, shape, size and the dimensions of pollen grains for each Aronia mitschurinii genotypes were determined by using a scanning electron micrograph (SEM).

\section{Morphometric characteristics}

The measurement of morphometric parameters was carried out on 50 pollen grains from each genotype using the AxioVision Rel. 4.8.2.0 program. The measurements were made in micrometers $(\mu \mathrm{m})$. The characterization of pollen grains was calculated by taking the following parameters: the polar axis ( $P$ - line connecting the proximal and distal pole), the equatorial axis ( $E$ - a line perpendicular to the polar axis and located in the equatorial plane).

\section{Statistical analysis}

Basic statistical analyses were performed using PAST 2.17; hierarchical cluster analyses of similarity between genotypes were computed on the basis of the Bray-Curtis similarity index; multi-dimensional scaling (MDS) analyses were performed in PRIMER (Clarke and Gorley, 2006). Variability of all these parameters was evaluated using descriptive statistics. Level of variability determined by Stehlíková (1998).

\section{Results and discussion}

This study of pollen morphology of tested Aronia mitschurinii showed that pollen grains are radially symmetrical, isopolar and according to the localization of apertures are zonotricolpate. Three compound apertures are according to distribution equidistant. The size, shape of pollen grains and number of apertures are documented on Figure 1.

Pollen grains oblong-ellipsoid, the apertures are long. In the received pictures it is clearly seen that the pollen grains of the presented blackberry breeds are 3 - and 4 - colporate. In polar view pollen grains are circular and triangular with straight or convex sides, in equatorial view - elliptical. Colpi, with uneven edges and pointed or blunted ends, almost converge at the poles. Colpi have granular membrane. Colpi are elliptic, longitudinal and elongated with straight or orbicular-dentate edges. Texture is sinuous-tuberculate in equatorial zone and finely bumpy in polar zone.

The polar axis $(P)$, equatorial diameter $(E)$ and polar axis to equatorial diameter $(P / E)$ ratio of pollen grains of nine Aronia mitschurinii phenotypes were measured using scanning electron microscopy (SEM), and the results are displayed in Table 1. An important morphological characteristic is the size of pollen grains. The length of polar axis $(P)$ varied from 34.16 to $50.14 \mu \mathrm{m}$ and the width of the equatorial axis $(E)$ was in the range of $16.10-25.24 \mu \mathrm{m}$. The values of variation coefficient were in the range of $4.20-5.84 \%$ for polar axes and in the range of $6.31-9.28 \%$ for equatorial axes. 
Grygorieva, O., Klymenko, S., Vinogradova, Y., Motyleva, S, Gurnenko, I., Narcyz, P., Brindza, J.

Agr.bio.div. Impr. Nut., Health Life Qual., 2018, 49-56
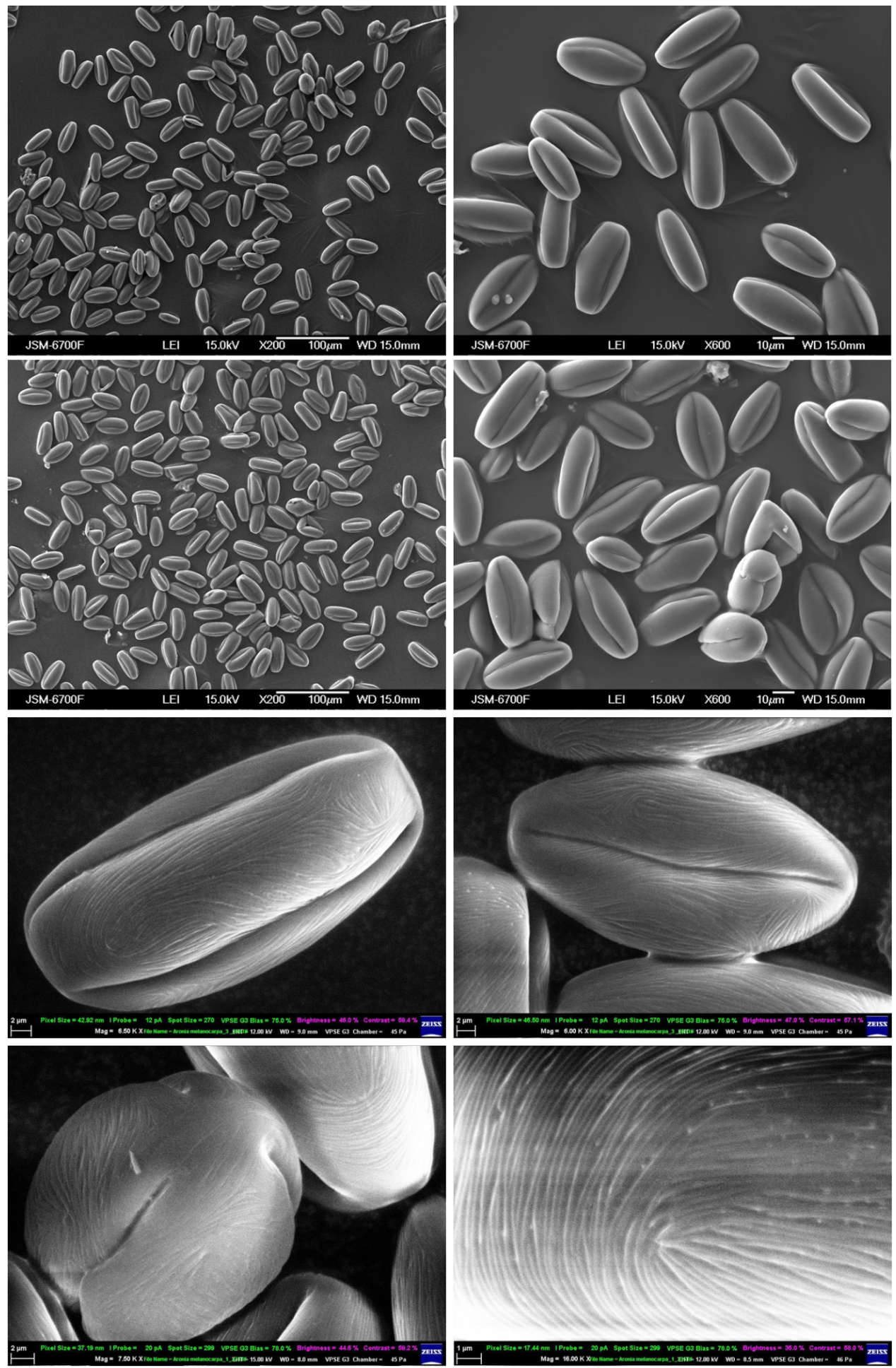

Figure 1 Pollen grains of Aronia mitschurinii A.K. Skvortsov \& Maitul. species in different positions (Photo: Gurnenko, 2018; Motyleva, 2018) 
Grygorieva, O., Klymenko, S., Vinogradova, Y., Motyleva, S, Gurnenko, I., Narcyz, P., Brindza, J. Agr.bio.div. Impr. Nut., Health Life Qual., 2018, 49-56

Table 1 The measured pollen morphological traits of selected phenotypes of Aronia mitschurinii A.K.Skvortsov \& Maitul.

\begin{tabular}{|c|c|c|c|c|c|c|c|c|c|}
\hline \multirow[t]{2}{*}{ Phenotypes } & $\min$ & $\max$ & CV \% & $\min$ & $\max$ & CV \% & $\min$ & $\max$ & CV \% \\
\hline & \multicolumn{3}{|c|}{ P - Polar axis $(\mu \mathrm{m})$} & \multicolumn{3}{|c|}{ E - Equatorial axis $(\mu \mathrm{m})$} & \multicolumn{3}{|c|}{ SI - shape index $(P / E)$} \\
\hline AM-01 & 39.78 & 47.39 & 5.10 & 17.47 & 23.58 & 8.02 & 1.68 & 2.53 & 10.41 \\
\hline AM-02 & 40.14 & 50.10 & 5.84 & 18.99 & 25.24 & 6.55 & 1.70 & 2.45 & 7.97 \\
\hline AM-03 & 39.38 & 49.12 & 4.65 & 19.35 & 23.96 & 6.71 & 1.80 & 2.43 & 8.82 \\
\hline AM-04 & 36.53 & 47.12 & 5.48 & 18.49 & 24.29 & 6.67 & 1.63 & 2.30 & 8.64 \\
\hline AM-05 & 38.95 & 50.14 & 5.56 & 19.10 & 25.00 & 6.31 & 1.74 & 2.32 & 7.83 \\
\hline AM-06 & 41.26 & 49.38 & 4.55 & 16.51 & 22.09 & 7.40 & 1.90 & 2.91 & 8.54 \\
\hline AM-07 & 40.69 & 49.50 & 4.20 & 16.94 & 22.35 & 7.34 & 1.93 & 2.59 & 7.50 \\
\hline AM-08 & 34.16 & 41.77 & 5.47 & 16.10 & 20.29 & 6.38 & 1.80 & 2.48 & 7.78 \\
\hline AM-09 & 39.04 & 47.92 & 5.15 & 16.23 & 24.28 & 9.28 & 1.83 & 2.85 & 10.99 \\
\hline
\end{tabular}

Note: min - minimum value; max - maximum value; CV - variation coefficient (\%).

Shape index (SI) of pollen grain depends on parameters of polar $(P)$ and equatorial $(E)$ axis. Shape index (the $P / E$ ratio) of tested species varied from 1.63 to 2.91 . Mean values of morphological parameters of pollen demonstrated on Figure 2. According to the average values, the phenotype AM-08 has the smallest pollen grains $38.00 \times 18.22 \mu \mathrm{m}$ (Figure $2 \mathrm{~A}$ ). On the dendrogram (Figure 2B), you can see that the phenotype AM-08 is really separated from the other samples. According to literary data, Aronia mitschurinii is a facultative apomict, and all her cultivars have only one genotype (Persson-Hovmalm et al., 2004; Vinogradova and Kuklina, 2014).

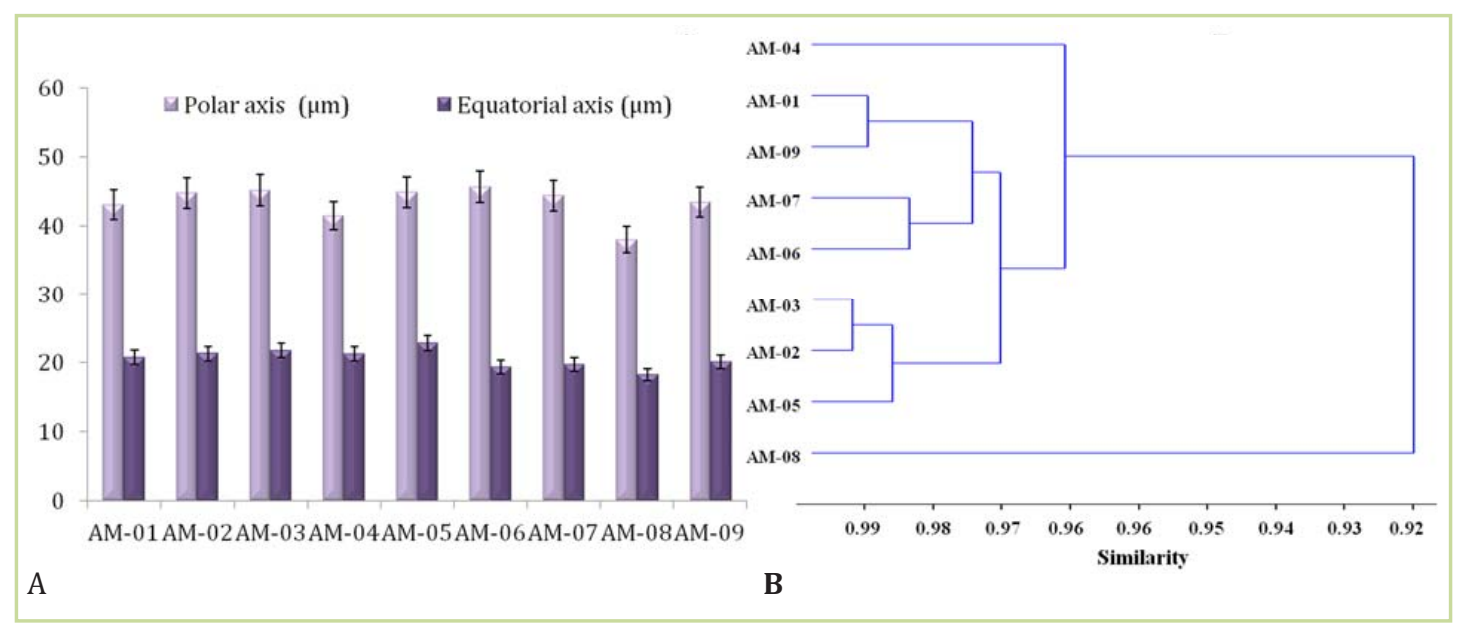

Figure 2A-B The average values and dendrogram of Aronia mitschurinii A.K. Skvortsov \& Maitul. 9 phenotypes based on morphometric characteristics of pollen Conclusions 
However, such a significant difference in the AM-08 phenotype compare with other samples still suggests the possibility of generation some genetic changes in the introduction population. Perhaps they are associated with hybridization or with accumulation of phenetic micromutations, which are not uncommon in botanical gardens, where samples of different geographical origin are cultivated close to each other. In the future, we propose to study the nature of these differences by molecular genetic methods.

\section{Conclusions}

Morphology characteristics of pollen grains of any genotypes and cultivars are important for breeding programmes and the studing of germplasm. Thus, the detailed pollen morphological and micro-sculptural characteristics of 9 phenotypes was investigated by using scanning electron microscopy. The analysis of morphological characteristics of pollen showed significant differences among Aronia mitschurinii phenotypes concerning the dimensions of pollen grain (length, width, and their ratio). Some of the pollen morphological parameters analysed be used for identification of Aronia mitschurinii phenotypes.

\section{Acknowledgements}

The publication was prepared with the active participation of researchers in international network AgroBioNet within the project ITMS 25110320104 Innovation of test methods and procedures for the detection of sources of bioactive substances for the improvement of health and quality of life. The author is grateful Polish National Commission for UNESCO. Experimental activities were realized in laboratories of Excellent centre for the conservation and use of agrobiodiversity at the Faculty of Agrobiology and Food Resources, Slovak University of Agriculture in Nitra.

\section{References}

ADAMCHUK, L., BILOTSERKIVETS, T., ŠIMKOVÁ, J. 2017. Nectar and Pollen Productivity of Common Chicory. In Agrobiodiversity for improving nutrition, health and life quality, vol. 1, p. 1-7. http:// dx.doi.org/10.15414/agrobiodiversity.2017.2585-8246.1

AHMEDULLAH, M. 1983. Pollen morphology of selected Vitis cultivars. In J. Amer. Soc. Hort. Sci., vol. 108, p. $155-160$.

ARZANI, K., NEJATIAN, M.A., KARIMZADEH, G. 2005. Apricot (Prunus armeniaca) pollen morphological characterisation through scanning electron microscopy, using multivariate analysis. In N. Z. J. Crop Hort. Sci., vol. 33, p. 381-388.

BRINDZA, J. BROVARSKYI, V. 2013. Pollen and bee pollen of some plant species. Kyiv : Korsunskiy vidavnichiy dim «Vsesvit». $137 \mathrm{p}$.

BROVARSKYI, V., VELYCHKO, S., BRINDZA, J., ADAMCHUK, L. 2017. Develoment and Testing of the Technology of Production of te Beebread With the Use of Artificial Combs. In Agrobiodiversity for improving nutrition, health and life quality, vol. 1, p. 31-42. http://dx.doi.org/10.15414/ agrobiodiversity.2017.2585-8246.31-42

DYAKOVA, I. 2014. Pollen morphology of the genus Malus Mill. In Modern Phytomorphology, vol. 6, p. 129-132. https://doi.org/10.5281/zenodo.160613 
ERDTMAN, G. 1966. Pollen morphology and plant taxonomy: Angiosperms. Hafner Publishing Company, New York, NY.

FOGLE, H.W. 1977. Identification of tree fruit species by pollen ultrastructure. In J. Amer. Soc. Hort. Sci., vol. 102 , p. $548-551$.

GRYGORIEVA, O., BRINDZA, J., OSTROLUCKÁ, M.G., OSTROVSKÝ, R., KLYMENKO, S., NÔŽKOVÁ, J., TÓTH, D. 2010. Pollen characteristics in some persimmon species (Diospyros spp.). In Agriculture [online], vol. 56(4), p. 121-130 [cit. 2018-09-16]. Available at: https://www.researchgate.net/ publication/303719651

GRYGORIEVA, O., MERTVISHEVA, M. 2013. Date plum (Diospyros lotus L.). In Pollen and bee pollen of some plant species (Brindza J., Brovarskyi V.). Korsunskiy vadavnichiy dim Vsesvit, p. 52-61.

GRYGORIEVA, O., MOTULEVA, S., NIKOLAIEVA, N., KLYMENKO, S., SCHUBERTOVÁ, Z., BRINDZA, J. 2017. Pollen grain morphological characteristics of American persimmon (Diospyros virginiana L.). In Agrobiodiversity for Improving Nutrition, Health and Life Quality, p. 151-158. http://dx.doi. org/10.15414/agrobiodiversity.2017.2585-8246.151-15

GRYGORIEVA, O., NIKOLAIEVA, N., BRINDZA, J., KLYMENKO, S. 2015. Pollen and bee pollen features of sweet chestnut (Castanea sativa Mill.). In Scientific Bulletin of the National University of Life and Environmental Sciences of Ukraine. Series: Technology of production and processing of livestock products [online], vol. 223, p. 35-40 [cit. 2018-09-16]. Available at: http://journals.nubip.edu.ua/ index.php/Tekhnologiya/article/view/6739/0

CHLEBO, R., ADAMCHUK, L. 2017. Pollen Natural Resources For Bees In Slovakia. In Agrobiodiversity for improving nutrition, health and life quality, vol. 1, p. 70-75. http://dx.doi.org/10.15414/ agrobiodiversity.2017.2585-8246.70-7

JAVADY, T., ARZANI, K. 2001. Pollen morphology of five Iranian olive (Olea europaea L.) cultivars. In J. Agric. Sci. Technol. [online], vol. 3, p. 37-42 [cit. 2018-09-16]. Available at: http://jast.modares. ac.ir/article-23-3710-en.pdf

KUKLINA, A.G., VINOGRADOVA, YU.K., TKACHEVA, E.V. 2015. About Flowering Biology of Alien Species: 3. Caragana arborescens Lam. and C. laeta Kom. In Russian Journal of Biological Invasions, vol. 6(4), p. 238-251. https://doi.org/10.1134/S2075111715040037

MARTENS, J. FRETZ, T.A. 1980. Identification of eight crabapples by pollen surface sculpture. In J. Amer. Soc. Hort. Sci., vol. 105, p. 257-263.

MERT, C. 2009. Pollen Morphology and Anatomy of Cornelian Cherry (Cornus mas L.) Cultivars. In HortScience [online], vol. 44(2), p. 519-522 [cit. 2018-09-16]. Available at: http://hortsci. ashspublications.org/content/44/2/519.full.pdf + html

MIAJA, M.L., RADICATI, L., PORPORATO, M., CARAMIELLO, R., FOSSA, V., VALLANIA, R. 2000. Morphophysiological observations on pollen of sour cherry (Prunus cerasus L.). In Acta Hort., vol. 514, p. 311-318.

MOTYLEVA, S., BRINDZA, J., KULIKOV, I. 2017. The morphology of pollen grains of the some species of Rosaceae Juss. family. In Agrobiodiversity for improving nutrition, health and life quality, vol. 1, p. 338-341. http://dx.doi.org/10.15414/agrobiodiversity.2017.2585-8246.338-341

NIKOLAIEVA, N.V., GRYGORIEVA, O.V., BRINDZA, J., GARKAVA, K.G., KLYMENKO, S.V. 2014. Morphological features of pollen Corylus avellana L. and Castanea sativa Mill. as indicator of environmental changes. In Plodovodstvo i yagodovodstvo Rossii: sbornik nauchnyih rabot, vol. 40(1), p. 232-238.

PERSSON-HOVMALM, H.A., JEPPSSON, N., BARTISH, I.V., NYBOM, H. 2004. RAPD analysis of diploid and tetraploid populations of Aronia points to different reproductive strategies within the genus. In Hereditas, vol. 141(3), p. 301-312. https://doi.org/10.1111/j.1601-5223.2004.01772.x 
RADOVIĆ, A., NIKOLIĆ, D., MILATOVIĆ, D., ĐUROVIĆ, D., TRAJKOVIĆ, J. 2016. Investigation of pollen morphological characteristics in some quince (Cydonia oblonga Mill.) cultivars. In Turkish Journal of Agriculture and Forestry, vol. 40, p. 441-449. http://dx.doi.org/10.3906/tar-1511-76

ROUHAKHSH, H., DAVARYNEJAD, G., ABEDI, B., RAHEMI, M. 2014. Pollen grain morphological characteristics of ten Iranian jujube (Ziziphus jujuba) cultivars by using scanning electron microscopy. In Advances in Environmental Biology [online], vol. 8(5), p. 1333-1338 [cit. 2018-0916]. Available at: http://www.aensiweb.com/aeb.html

VINOGRADOVA, YU.K. 2012. Bioraznoobrazie taksonov roda Solidago L. po mikromorfologicheskim priznakam [Biodiversity of Solidago L. taxa on the micromorphological characteristics] In Bioraznoobrazie: problemyi izucheniya i sohraneniya. Materialyi mezhdunarodnoy nauchnoy konferentsii. Tver, p. 346-350 (In Russian).

VINOGRADOVA, YU.K., KUKLINA, A.G. 2014. Aroniya Michurina: ot sozdaniya do naturalizatsii [Aronia mitschurinii: from origination to naturalization]. M., GEOS, 137 p. (In Russian). ISBN 978-5-89118-667-5.

VINOGRADOVA, YU.K., TKACHEVA, E.V., BRINDZA, J., MAYOROV, S.R., OSTROWSKY, R. 2013. On flowering patterns of alien species: 2. Robinia pseudoacacia, $R . \times$ ambigua, and R. neomexicana. In Russian Journal of Biological Invasions, vol. 4(2), p. 74-86. https://doi.org/10.1134/S2075111713020094

VINOGRADOVA, YU.K., TKACHEVA, E.V., MAYOROV, S.R. 2012. About Flowering Biology of Alien Species: Lupinus polyphyllus Lindl. In Russian Journal of Biological Invasions, vol. 3(3), p. 163-171. http:// dx.doi.org/10.1134/S2075111712030083

WESTWOOD, M.N., CHALLICE, J.S. 1978. Morphology and surface topography of pollen and anthers of Pyrus species. In J. Amer. Soc. Hort. Sci., vol. 103, p. 28-37. 